\title{
Towards a Sustainable Governance of Information Systems: Devising a Maturity Assessment Tool of Eco-Responsibility Inspired by the Balanced Scorecard
}

\author{
Amélie Bohas and Laïd Bouzidi \\ Team Magellan, Group SICOMOR, University Jean Moulin Lyon 3, France \\ \{amelie.bohas, laid.bouzidi\}@univ-1yon3.fr
}

\begin{abstract}
The assessment of the maturity of Information System (IS) regarding its contribution to corporate social responsibility policy is considered as a stake for organizations. However, few research efforts have been dedicated to this evaluation and even less to the elaboration of a management tool. This paper adopts an engineering perspective to develop a performance assessment approach in this field. Theoretically, this communication (1) mobilizes the methodology of engineering research to build a measurement system of the IS maturity in relation to the economic, social and environmental performance, (2) extends the researches about the sustainable balanced scorecard (SBSC) to the field of IS governance. Practically, this study provides organizations with a global approach to this complex phenomenon as well as a guide to assess it. The originality of this research lies in the application of the conceptual framework of the SBSC to a new research domain.
\end{abstract}

Keywords: information system governance, CSR policy, sustainable balanced scorecard, maturity measure, engineering research.

\section{$1 \quad$ Introduction}

In a context of global warming and depletion of resources, practitioners and researchers tend to worry in an increasing way about the role of ICTs (Information and Communication Technologies) towards the environment. Indeed, if the technologies had remained exempt up to now from a reflection on their environmental impacts because of their "immaterial" presupposed character, they entered recently into the heart of the political debate and the professional concerns [1], [2], including professional associations (ADEME, CIGREF, SYNTEC, etc.) and websites (GreenIT.fr, ecoinfo.cnrs.fr...) which are dedicated to it. On the academic level, there are a growing number of publications proposed on this topic every year [3-6] that give evidence of the scientific interest in this emergent problem.

In October 2009, the CIGREF (Professional association of French companies and organizations from all sectors using information systems) published a report on "Ecoresponsible information systems" and especially "the use of ICT in the service of sustainable business." In this document, it identified three key issues for the future: 
- "To ensure the accompanying change of users through awareness, training and education, in thinking about the ways to consume less and work differently;

- To optimize the ICT sector, by developing technical and organizational innovation and eco-design, and creating eco-labels covering hardware, software and services benefits;

- To exploit the potential of the ICT sector to help other sectors to develop sustainably, by rethinking their processes and their trades, and reduce their carbon footprint." [7, p. 2]

These last two issues invite a dialectical reflection on one hand on the liability of the information system (IS) in the environmental problems [4], [8], [9] that organizations and society as a whole are currently facing and conversely on the possible contribution of the IS to the sustainability of ecosystems on the other hand [5], [10-14].

To reduce the impact of IT on the environment and put their IS in the service of the CSR policy, organizations should implement practices that contribute to the reduction of their energy consumption, extending the life cycle of their hardware (only real solution to limit the volume of WEEE), limiting the consumables (paper, ink cartridges, etc.), and creating new economic and ecologic opportunities (eco-innovation, smart building, supply chain optimization, among others) as shown in Table 1.

Table 1. Sample of actions to reduce the environmental impact of IS organization

\begin{tabular}{ll}
\hline ICT life cycle phase & Issues for organizations \\
\hline Production & Responsible procurement policy: eco-labels \\
& Lobbying computer manufacturers \\
& Lengthening of the frequency of renewal of \\
computer parks & \\
& Measures to reduce energy consumption \\
and the volume of consumables & Education and training of employees to \\
consume less and work differently & Regulation compliance \\
& Extension of the life cycle of materials \\
End of life & Reduction of the amount of e-waste \\
\hline
\end{tabular}

So, as regards IS, the stake for every organization is to work towards "a responsible attitude, to question its way of functioning, its mode of consumption, and its relation to the computer object" $[13, \mathrm{p} .2]$. To this end, it has to define new goals for action, new mechanisms of government and integrate new designs of IS. Also, it appears that governance is a key issue in the implementation of actions related to sustainable development (SD). Then the question arises to business executives, chief information officers (CIOs) and IT managers in particular, is "how to assess the ecoresponsibility of IS and its alignment with CSR policy?" Indeed, although there is a growing concern about this thematic in organizations, it still lacks, for the majority of them, a system of evaluation of the performances [15]. 
In this context, the objectives of this paper are twofold. Firstly, to expose the theoretical framework of the eco-responsible maturity of IS and of its governance. Secondly, and this is the main contribution of this paper, to propose an approach, based on an adaptation of the model of the Balanced Scorecard, which will enable companies to assess the eco-responsible maturity of IS and its governance. Derived steering model result of an engineering research approach led since October 2011 in partnership with a consulting firm specialized in "eco-responsible IS."

\section{Theoretical Framework}

\subsection{Emergence of Responsible IS}

The transformations engendered by the new ICT were numerous since their advent, which were of social, economic or systemic order. In particular, digital uses allowed abolishing the boundaries of space and time of action - individual or collective thanks to the immediacy of the flows they generate contributing to the emergence of a network society [16]. Also, they gave rise to their subject to much speculation. So as underlined it Crozier and Friedberg [17, p.36], "we believed to see in the computer the technical instrument making possible self-management" before noticing that "without new organizational capacities, [it] is only an additional instrument of routinisation." Even of constraint if we refer to certain structurationist works in IS. Recently other "bad" assumptions were raised by Rodhain and Fallery [13] on the subject this time of their role in the environment.

But this awareness is not limited to the environmental dimension of ICT, it corresponds to a more global reflection which questions the connection between IS and SD as evidenced by works as "ICTs and sustainable development" [18] and "Information system and sustainable development" [19] If the concept of SD is present in numerous works in strategic management [20], [21], its link with works in IS may seem surprising so much practices implemented in IS remain deeply antithetical, and at the very least antagonistic, with the principles of sustainability [13], [22-24].

Ethical reflection is however not new in IS since following the works of Foucault (in what is called the "last Foucault" under the three phases of reflection which we can identify as the philosopher's), authors such as Zuboff [25] were able to blame the technologies for their panoptic effect as far as they enable surveillance of people and even a certain control with regard to their "informing" effect. The words of the latter besides never had much echo than at time of unbridled development of the systems of video surveillance but also "smartphones" and all the applications and techniques of geo-localization they integrate.

However never until now has this reflection been pursued as far as this analysis by questioning simultaneously the economic, social and environmental dimensions. These three concerns corresponds to the "three pillars of sustainable development" that organizations have to manage to reconcile in their activities.

The connection of the concept of CSR with that of SD was concretized through the recent publication of the standard ISO 26000 that gives the following definition of CSR: the corporate social responsibility is the contribution of organizations to 
sustainable development [26]. Each organization must answer for its acts and in particular its environmental or social impacts and behave in full transparency by reporting its activities with its stakeholders and more broadly with the society.

"The organizational IS (or this part of the IS) dedicated to the data capture, collection, processing and dissemination of information related to CSR can be described as IS Responsible.” [3, p.3] These new functions assigned to IS are not the only ones. Thus, Faucheux and al. [18] identified at least three typologies of ICT with regard to their contribution to SD, as shown in Table 2.

Table 2. Typologies of ICT with regard to their contribution roles to sustainability

\begin{tabular}{|c|c|}
\hline Typology according to... & Role of ICT \\
\hline ...their use function & $\begin{array}{l}\text { - Observation and analysis for assistance } \\
\text { to the decision } \\
\text { - Management and protection of the } \\
\text { Environment } \\
\text { - Education and dissemination of } \\
\text { knowledge }\end{array}$ \\
\hline$\ldots$ the objectives achievable in the short term & $\begin{array}{l}\text { - Role of catalyst } \\
\text { - Role of quantifier }\end{array}$ \\
\hline$\ldots$ the degree of innovation & $\begin{array}{l}\text { - Standardisation, control and manage- } \\
\text { ment } \\
\text { - Adaptation /substitution } \\
\text { - Radical Innovation }\end{array}$ \\
\hline
\end{tabular}

\subsection{The Balanced Scorecard as a Suitable Sustainable Performance Measurement Approach}

"The balanced scorecard is a strategic management system that links performance measurement to strategy using a multidimensional set of financial and nonfinancial performance metrics." [27, p.2] This new approach was devised at the beginning of the 90 s by Kaplan and Norton [28-30] in response to the hegemony of the financial indicators for the measurement of performance. It articulates in a same scheme the strategic vision of the firm with corporate goals and specific measures of performance within a set of four perspectives related to the cores values of the company: financial, customer, internal business processes and organizational learning and growth.

This ability of BSC to interconnect several dimensions of performance and to integrate non-monetarized factors led some researchers and firms to view this strategic management system as a relevant approach to implement a sustainability strategy and to drive global performance. As Figge et al. [31, p.272] said, "such an approach to sustainability management aims at a simultaneous achievement of ecological, social and economic goals" and thus BSC makes it possible to overcome the traditional conflicts that can exist between these three performance dimensions.

In this perspective, several authors have studied "the process and steps of formulating a Sustainability Balanced Scorecard” [31, p.269]. Three main ways of implementation were identified: 
1. The incorporation of social and environmental indicators in the existing set of measures of each perspective. These "sustainability key success factors" [27, p.7] deepen the performance measurement without changing the model structure.

2. The creation of a fifth sustainability perspective which seems to be suitable for firms who have identified this dimension as a strategic core aspect for its success. This introduction of a new perspective expands the model towards non markets aspects and communicates the importance of the sustainability strategy.

3. The "deduction of a derived environmental and social scorecard" [31, p.275]. This specific environmental and social scorecard represents an extension of the conventional BSC and aims to drive specifically the ecological and social metrics.

The various advantages of the BSC for the integration of sustainability management are listed in the Table 3.

Table 3. The BSC as a suitable framework to implement sustainability

\begin{tabular}{|c|c|}
\hline Authors & Advantages \\
\hline $\begin{array}{l}\text { Epstein-Wisner, } \\
2001 \text { [27, p.9] }\end{array}$ & $\begin{array}{l}\text { "It increases social and environmental accountability by explicitly } \\
\text { including performance metrics related to social and environmental } \\
\text { goals, and by recognizing their interconnection with a multidimen- } \\
\text { sional set of corporate objectives." }\end{array}$ \\
\hline $\begin{array}{l}\text { Epstein-Wisner, } \\
2001 \text { [27, p.9-10] }\end{array}$ & $\begin{array}{l}\text { "In addition, incorporating social and environmental metrics into the } \\
\text { balanced scorecard can help senior managers reposition their organiza- } \\
\text { tions toward improved corporate responsibility." }\end{array}$ \\
\hline $\begin{array}{l}\text { Figge et al. } 2002 \\
{[31, \text { p.273] }}\end{array}$ & $\begin{array}{l}\text { "An SBSC fulfils the central requirement of the sustainability concept } \\
\text { for a permanent improvement of the business' performance in eco- } \\
\text { nomic, ecological and social terms." }\end{array}$ \\
\hline $\begin{array}{l}\text { Figge et al. } 2002 \\
{[31, \text { p.283] }}\end{array}$ & $\begin{array}{l}\text { "It helps significantly to overcome the short-comings of the often par- } \\
\text { allel approaches of environmental, social and economic management } \\
\text { systems implemented in the past." }\end{array}$ \\
\hline
\end{tabular}

However, despite arguments in favour of the use of the BSC approach to manage a sustainability strategy, some authors have reservations about the real effectiveness of this model. Thus, for Quairel [32], SBSC can't be considered as a global performance management tool since it doesn't take into consideration the social and environmental performance not related to the economic performance. Moreover it seems that finally informed indicators are essentially monetary and conversely qualitative aspects are very weakly taken into account and the relations of cause and effects very little studied. Besides, Zingales and Hockerts [33] underlined the limits of the approach through the study of several case studies of companies integrating environmental and social issues in a BSC. In practice, they noticed a lack of alignment of environmental management with the BSC and a frequent misuse of the tool associated with measures 
rarely updated. They also suggested some hypothesis regarding the success factors of "the causal relationship between the Balanced Scorecard use and Sustainability" such as the presence of an "Environmental / Sustainability manager" [33, p.12].

At present, concerning the appropriateness of BSC for IS management, some authors have already used BSC methodology to measure IT project success [34], to "achieve IT-business strategic alignment" [35, p.173] or even more recently "to drive and check the performance of a green storage policy" [36, p.1].

\section{Methodological Device}

The assessment of the eco-responsible maturity of IS is an emergent phenomenon which is complex as it is "simultaneously multi-criteria, multi-actors, multi-rational, and evolutionary" [37, p.2]. In our knowledge, this academic study on the devising of an assessment tool of the eco-responsible maturity of IS is a first, at least in France. This favours the implementation of engineering research that comes within the scope of a constructivist epistemology.

Table 4. Main features of the engineering research: the devising of an assessment tool of the eco-responsible maturity of IS in a consulting firm

\begin{tabular}{ll}
\hline Dimensions & Organisation \\
\hline Organizational structure & $\begin{array}{l}\text { Consulting firm in eco-responsible IS - 5 } \\
\text { employees }\end{array}$ \\
Period of study & $\begin{array}{l}\text { October } 2011 \text { - June } 2012 \\
\text { Evaluation of the eco-responsible maturity } \\
\text { of IS and its governance }\end{array}$ \\
$\begin{array}{l}\text { Member of the team in charge of the devel- } \\
\text { tion }\end{array}$ & $\begin{array}{l}\text { opment and scientific validation of the tool } \\
\text { Test of the tool with user companies }\end{array}$ \\
$\begin{array}{l}2 \text { IS eco-responsible maturity diagnostic } \\
\text { studies planned between January 2012 and } \\
\text { June 2012 }\end{array}$ \\
$\begin{array}{l}\text { Scientific and professional literature on the } \\
\text { subject, internal documents, interview with } \\
\text { experts and interview with the CIO of user } \\
\text { companies }\end{array}$ \\
\hline
\end{tabular}

"Engineering research is similar in some ways to the action-research by the fact that it focuses on organizational change processes and that it involves the actors affected by the change in the approach of research. It differs however, in devising a new status of "scientist-engineer" that develops its research support tool, built it, and is both as organizer and appraiser of its implementation in organizations, contributing in 
doing so to the emergence of representations and new scientific knowledge. These scientific knowledge are procedural and not substantive in nature, and are intended to provide a guide to "organizational engineering", to build complex problems and drive processes." [37, p.1] Table 4 presents the main features of this engineering research.

\subsection{The Elaboration of the Scorecard}

We began the empirical study by modelling the actual knowledge of the consulting firm about the eco-responsible maturity of IS. They had already identified ten technical domains of assessment: data centre, waste, IT purchase, uses, CSR, governance, printing, tele-work and transport, work station and software, environmental management software. For each domain, they had defined several sub-domains, processes and sub-processes. This resulted in a complex system with an abundance of detailed information about many aspects but with no links between all these elements. As the various domains were not interconnected, we obtained a fragmented view of the maturity of IS towards sustainability. Consequently, there was a need to link performance measures and summarize these elements in global perspectives so "that managers be able to view performance in several areas simultaneously" [28, p.72].

So inspired by the BSC of Kaplan and Norton, we presented to the consulting firm a new approach to devise the tool, based on a vision by "perspective" instead of a division by "process" as they had previously proposed it. In the same logic, we assumed that behind the questions in the consulting firm's scorecard, it exists a vision of what is an IS eco-responsible and that this one could be translated into perspectives.

Thus, we defined four important perspectives and we classified the technical subdomains and sub-processes previously defined by the firm according to their pertaining to one or other of these perspectives. Afterwards, for each of one, we formulated four global objectives in connection with the technical sub-domains and sub-processes.

Then we established a representation, under the shape of a map of the four perspectives, of the wished scorecard by limiting the number of measures used and agreeing on a certain number of clusters to be made to simplify the current model and avoid any redundancy.

Finally, we assigned for each question and indicator up to two objectives. In this way, the achievement of one objective is measured through several questions and indicators but this objective belongs to only one perspective. Figure 2 gives a representation of the structure of the scorecard.

In conclusion, as for the BSC, we operationalized the vision of the eco-responsible IS through four perspectives which were then translated into four general goals. Finally the latter were associated with specific measures.

In the process of assessment conducted by the consulting firm to its clients, the aim is to measure the good fit between the values of indicators and questions found within the company with the objectives defined previously according what we defined as a mature responsible IS. 


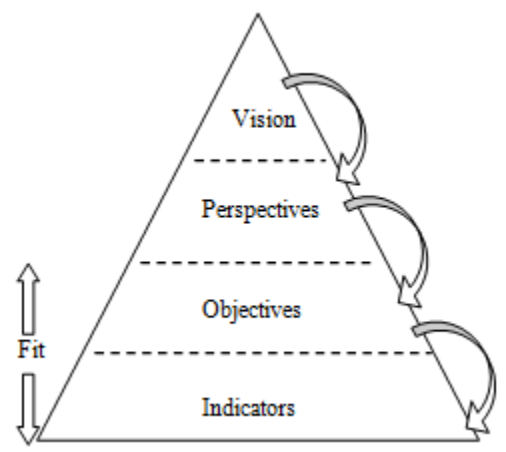

Fig. 1. The logic of the tool

\section{$4 \quad$ Results}

To define the four perspectives, we considered the ones existing in the BSC, those of the Skandia navigator and the three pillars of SD. These four dimensions are described below.

\subsection{Economic Perspective: "What Is Necessary to Bring to Our Economic Stakeholders?"}

The economic perspective gathers the imperatives of the "Financial" and "Customer" dimensions of the conventional BSC. Indeed, it takes into account, in the IS field, the economic issues as the search for a "competitive advantage (through factors such as corporate image, reputation and product differentiation)" [27, p.8] and the trade-offs between the conflicting interests of the different stakeholders.

On the financial aspect, the economic perspective incorporates indicators of costs savings, productivity gains, profitability and some key financial measures for the IT performance as the Return on Investment (ROI) or even the Total Cost of Ownership (TCO). It also comprised non-monetary performance indicators such as legitimacy or reputation.

On the customer dimension, the economic perspective is concerned with striving to meet their needs and with all the objectives of a commercial policy. It reflects how IS contributes to the customer value creation. It also questions the implication of the considered company in the civil society and the role played by IS in this perspective.

Finally, this dimension evaluates the management of IT purchases and particularly the regulatory compliance, the policy management of the suppliers and the integration of Eco-labels criteria in the requests for proposal. 


\subsection{Human Perspective: "How to Leverage the Human Capital?"}

This perspective does not really exist as it is in the model of Kaplan and Norton, so we draw our inspiration both from the social pillar of SD and from the Skandia Navigator devised by Leif Edvinsson and Michael Malone in 1997 [38]. This scorecard differs from the BSC of Kaplan and Norton by adding a fifth Human perspective which is placed at the heart of the approach. It includes knowledge, experience, and competencies.

In this way, it is close to the "Learning and growth" perspective of the BSC which takes into account "qualification, motivation and goal orientation of employees" [31, p.271].

In our conception, the Human perspective integrates the human capital valorisation i.e. the consideration of the individual with its organizational knowledge.

The main areas considered in this dimension were the management of training, competences, work tools, work place and transport, uses, behaviours and eco-friendly gesture.

\subsection{Environmental Perspective: "How to Preserve the Environment?"}

The environmental Perspective includes all actions contributing to the preservation of the environment. These latter ones can be divided into three main categories which represent the main phases of IT life-cycle: conception, use and end-of-life.

We find in these areas preoccupations about the resources and raw material management, energy consumption, GHG emissions, WEEE management and consumable management.

There is another area in this perspective which does not concern the IT footprint on the environment but its potential of contribution to SD and particularly to the CSR policy of the firm.

\subsection{Management System Perspective: "How to Drive Change and Continuous Improvement?"}

The Management System Perspective covers some goals of the previous dimensions of "Internal Business Processes" and "Learning and growth" perspectives. It aims to evaluate "how well a company performs on key internal dimensions" [27, p.2]. It integrates measures on the three categories of performance simultaneously through evaluation areas which are Energy Consumption, Carbone Footprint, IT Purchases, Transport, Shareholders' Expectations, Compliance Regulatory, among others.

This perspective also "describes the infrastructure necessary for the achievement of the objectives of the other three perspectives" [31, p.271] and in particular it defines the organization and decision system. It is concerned with the elaboration of an IS eco-responsible charter which aims to disseminate values and good practices throughout the company. This perspective incorporates issues about support change and continuous improvement in the other three perspectives. It is therefore a transversal dimension. 


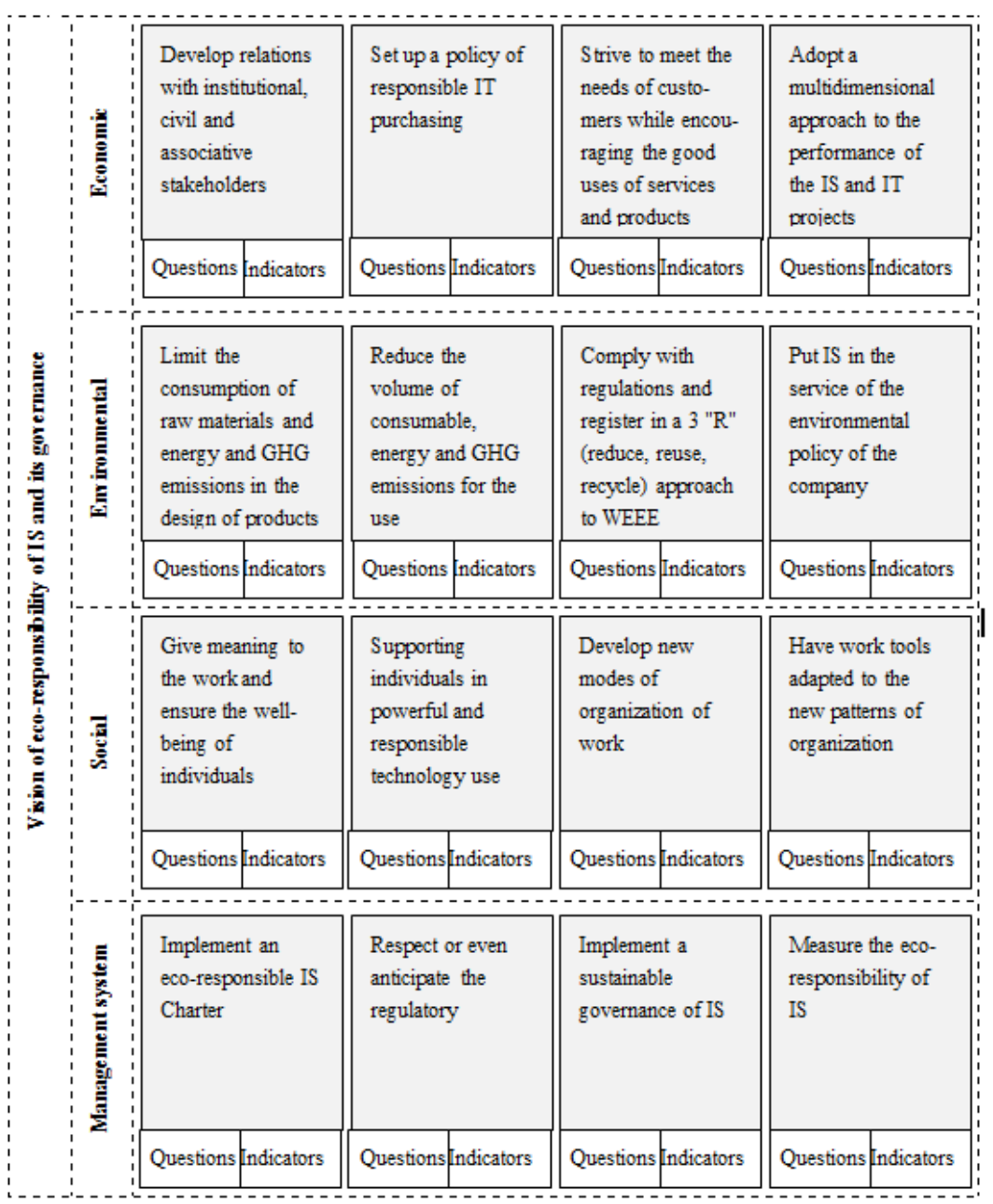

Fig. 2. Proposal of a scorecard of the eco-responsible maturity of IS and its governance

\section{Conclusion}

The ICT are not the immaterial devices we imagine them to be. They consume resources and generate abundant e-waste. It is only with the massive distribution of these technologies - as an example, the number of computers should reach 2 billion before 2014 [39] - that we became aware of all the negative externalities engendered by the production, the uses and the end of life of these products [4], [8]. But conversely, ICT can reduce emissions and thus contribute to sustainability in others sectors. Within firms, IS can be put at the service of CSR policy. The assessment of the maturity of the eco-responsibility of IS makes it possible to measure how IS performs 
in the ecological, social and economic perspectives. Evaluate the impact of IS on the environment and its contribution to sustainability represents a major stake for CIO.

In this paper, we wanted to expose the theoretical framework of the measurement of the eco-responsible maturity of IS and shown that this thematic originates from the interconnection with the concepts of SD and CSR in the field of IS. We saw that although the ethical reflection is not new in IS, it has never encompassed such variety of subjects simultaneously. Then we demonstrated that the logic of the BSC methodology could be relevant to formulate a measurement system of sustainability strategy even if some limits and conditions of success can be identified.

As there was a need for a measurement system of the maturity of the ecoresponsible IS, we devised a scorecard derived from the BSC in an engineering research approach.

The major interest of this tool is not to provide an exact measure of the ecoresponsibility of IS but to give a sense of responsibility to actors and to lead them to reflect on this subject in order to change their practices in a conscious way. Kaplan and Norton also emphasize that "the balanced scorecard should be used as a communication, informing, and learning system, not as a controlling system.” [29, p.25]

This scorecard enables one to give visibility to the actions carried out at the level of the IS and to provide consistency with the practices of CSR. Like this, it represents a tool for dialogue between DSI and Directions: "Through using a causal chain analysis to link performance metrics to business value and strategic objectives, managers have a tool to communicate the business value of sustainability actions to the CEO and $\mathrm{CFO}$ of the organization, to help justify resource allocations to EH\&S initiatives, and to tell the story of sustainability in business language." [27, p.10]

This study could be extended using this model in different organizational contexts. Like this, we could analyze (1) the transformations of actors' representations with the implementation of the tool and (2) the efficiency of the tool in helping to identify actions plans to improve the maturity of the eco-responsibility of IS.

\section{References}

1. Breuil, H., Burette, D., Flüry-Hérard, B., Cueugniet, J., Vignolles, D.: Rapport TIC et Développement durable, Ministère de l'Ecologie, de l'Energie, du Développement Durable et de l'Aménagement du Territoire, Ministère de l'Economie, de l'Industrie et de l'Emploi, p. 96 (December 2008)

2. Petit, M., Breuil, H., Cueugniet, J.: Rapport Développement éco-responsable et TIC (Detic) CGIET, Conseil Général de l'Industrie, de l'Energie et des Technologies (2009)

3. Pensel, J.L.: Les systèmes d'information au service de la responsabilité sociale d'entreprise. In: 14th AIM Symposium, Marrakech, Morocco, June 10-12 (2009)

4. Ait-Daoud, S., Laqueche, J., Bourdon, I.: Ecologie \& technologies de l'information de la communication: une étude exploratoire sur les éco-TIC. In: AIM Symposium, May 19-21, La Rochelle (2010)

5. Freeman, I., Hasnaoui, A.: Technologies de l'Information et de Communication: un outil pour implémenter et véhiculer la responsabilité sociale des entreprises (RSE). In: 15th AIM Symposium, May 19-21, La Rochelle (2010) 
6. Mathieu, A.-L., Bohas, A.: Une typologie de pratiques de Système d'information durables. In: 16th AIM Symposium, May 25-27, La Réunion (2011)

7. CIGREF, Systèmes d'information éco-responsable: l'usage des TIC au service de l'entreprise durable (2009)

8. Berkhout, F., Hertin, J.: Impacts of Information and Communication Technologies on Environmental Sustainability: Speculations and Evidence, p. 21. Report to the OECD. University of Sussex, Brighton (2001)

9. Hilty, L.M.: Information Technology and Sustainability: Essays on the Relationship Between ICT and Sustainable Development. BOD, Norderstedt (2008)

10. Hilty, L.M., Arnfalk, P., Erdmann, L., Goodman, J., Lehman, M., Wäger, P.A.: The relevance of information and communication technologies for environmental sustainability - A prospective simulation study. Environment Modelling \& Software 21, 1618-1629 (2006)

11. Fuchs, C.: Theoretical foundations of defining the participatory, co-operative, sustainable information society. Information, Communication \& Society 13(1), 23-47 (2010)

12. Deltour, F.: Peut-on produire des TIC vertes? Equipementiers et parties prenantes dans le débat sur le caractère écologique des TIC. In: 15th AIM Symposium, May 19-21, pp. 1921. La Rochelle (2010)

13. Rodhain, F., Fallery, B.: Après la prise de conscience écologique, les TIC en quête de responsabilité sociale. In: 15th AIM Symposium, May 19-21, pp. 19-21. La Rochelle (2010)

14. Pensel, J.L.: TIC et Parties Prenantes minoritaires: vers l'entreprise responsable. In: 15th AIM Symposium, May 19-21, pp. 19-21. La Rochelle (2010)

15. GARTNER: Green IT Initiatives Are Moving beyond Power and Cooling Efficiency, 8 February, $\mathrm{n}^{\circ}$ G00173836 (2010)

16. Castells, M.: The Rise of the Network Society. Blackwell Publishing, New York (2000)

17. Crozier, M., Friedberg, E.: L'acteur et le Système. Le Seuil, Paris (1977)

18. Faucheux, S., Hue, C., Nicolaï, I.: TIC et développement durable - Les conditions du success, p. 222. Editions De Boeck Université, Bruxelles (2010)

19. Tassin, P., Berhault, G., Berthoud, F., Bonnet, P., Bordage, F., Bordes, F., Delsol, E.: Systèmes d'information et développement durable - économie, société et environnement, p. 345. Publications Hermes Science, Editions Lavoisier, Paris (2010)

20. Martinet, A.-C., Reynaud, E.: Stratégies d'entreprise et écologie. Economica, Paris (2004)

21. Carroll, A.B.: A three dimensional conceptual model of corporate social performance. Academy of Management Review 4, 97-505 (1979)

22. Berthoud, F., Pons, J.-L., Drezet, E., Louvet, V.: Comment se diriger vers une informatique durable? In: Actes du JRES, Strasbourg, November 20-23 (2007)

23. Fuchs, C.: The implications of new information and communication technologies for sustainability. Environment, Development and Sustainability 10(3), 291-309 (2008)

24. Flipo, F., Gossart, C., Deltour, F., Gourvennec, B., Dobré, M., Michot, M., Berthet, L.: Technologies numériques et crise environnementale: peut-on croire aux TIC vertes? Rapport Ecotic (2009)

25. Zuboff, S.: In the Age of the Smart Machine. Basic Books, New York (1988)

26. AFNOR: PR NF ISO 26000: Lignes directrices relatives à la responsabilité sociétale (2010)

27. Epstein, M.J., Wisner, P.S.: Using a balanced scorecard to implement sustainability. Environmental Quality Management, 1-10 (Winter 2001)

28. Kaplan, R.S., Norton, D.P.: The Balanced Scorecard -Measures That Drive Performance. Harvard Business Review (January-February 1992)

29. Kaplan, R.S., Norton, D.P.: The Balanced Score-card: Translating Strategy into Action. Harvard Business School Press, Boston (1996) 
30. Kaplan, R.S., Norton, D.P.: The Strategy-Focused Organization: How Balanced Scorecard Companies Thrive in the New Business Environment. Harvard Business School Press, Boston (2000)

31. Figge, F., Hahn, T., Schaltegger, S., Marcus, W.: The Sustainability Balanced Scorecard: Linking Sustainability Management to Business Strategy. Business Strategy and the Environment 11, 269-284 (2002)

32. Quairel, F.: Contrôle de la performance globale et responsabilité sociale de l'entreprise (RSE). Association Francophone de Comptabilité, Tunis (2006)

33. Zingales, F., Hockerts, K.: Balanced Scorecard and Sustainability: Examples from Literature and Practice. CMER, Working Paper no 30, Insead (2003)

34. Martinsons, M., Davison, R., Tse, D.: The balanced scorecard: A foundation for the strategic management of information systems. Decision Support Systems 25, 71-88 (1999)

35. Huang, C.D., Hu, Q.: Achieving IT-business strategic alignment via enterprise-wide implementation of balanced scorecards. Information Systems Management 24(2), 173-184 (2007)

36. Laura, F., Coelho, F., Delmond, M.H.: Gestion durable des données: point sur les enjeux et proposition d'une démarche de pilotage de la performance appuyée sur un balanced scorecard thématique. In: 15th AIM Symposium, May 19-21, pp. 19-21. La Rochelle (2010)

37. Chanal, V., Lesca, H., Martinet, A.-C.: Vers une ingénierie de la recherche en sciences de gestion. Revue Française de Gestion 116, 41-51 (1997)

38. Edvinsson, L., Malone, M.: Intellectual Capital: Realizing Your Company's True Value by Finding Its Hidden Brainpower. Harper Business, New York (1997)

39. Gartner: Gartner Says More than 1 Billion PC. In: Use Worldwide and Headed to 2 Billion Units by 2014. Gartner Newsroom (2008), http: / /www.gartner.com/it/page.jsp?id=703807

40. SMART 2020: Enabling the low carbon economy in the information age United States Report Addendum. Report Addendum in The Climate Group, London (2008), http: / /www. mendeley.com/research/smart-2020-enabling-lowcarbon-economy-information-age-united-states-reportaddendum/ 